\title{
A NEW METHOD FOR THE QUANTITATIVE DETERMINATION OF PROTEIN OF BACTERIAL ORIGIN ON THE BASIS OF D-ASPARTIC ACID AND D-GLUTAMIC ACID CONTENT
}

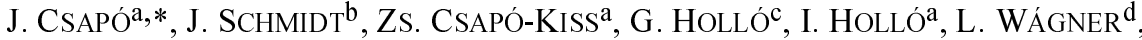 \\ É. CENKVÁRI ${ }^{b}$, É. VARGA-VISI ${ }^{\mathrm{a}}, \mathrm{G}$. POHN ${ }^{\mathrm{a}}$ and G. ANDRÁSSY-BAKA ${ }^{\mathrm{a}}$ \\ ${ }^{a}$ University of Kaposvár, Faculty of Animal Science, H-7401 Kaposvár, Guba Sándor u. 40. Hungary \\ ${ }^{b}$ West-Hungarian University, Faculty of Agricultural Science, Mosonmagyaróvár. Hungary \\ ${ }^{c}$ Szent István University, Faculty of Agricultural Sciences, Gödöllő. Hungary \\ ${ }^{\mathrm{d}}$ University of Veszprém, Georgikon Faculty of Agricultural Science, Keszthely. Hungary
}

(Received: 28 February 2000; accepted: 10 August 2000)

In the past years several methods have been developed for the determination of the proportion of the nitrogen-containing substances of microbial origin passed from the rumen into the abomasum or the small intestine. Recently, on examining the D-amino acid content of foodstuffs, particularly milk and milk products, it has been observed that, in addition to D-Ala, Dglutamic acid (D-Glu) and D-aspartic acid (D-Asp) can also be detected in similar quantities, primarily in products which have links with bacterial activity. This gave rise to the idea of examining the diaminopimelic acid (DAPA), D-Glu and D-Asp content of bacteria extracted from the rumen of cattle and that of chyme from the same cattle, in order to determine the type of relation existing among these three components, and to establish whether D-Asp and D-Glu can be used in the estimation of protein of bacterial origin. On determination of the DAPA, D-Asp and D-Glu content by means of amino acid analyser and high performance liquid chromatography of duodenal chyme from five growing bulls and of ruminal bacteria from the same bulls, the following values were established. For chyme (and, in brackets, for ruminal bacteria) $r$ value calculated by means of linear regression was $0.78(0.76)$ between DAPA and D-Asp, and 0.70 (0.81) between DAPA and D-Glu. The $r$ values between the crude protein content of ruminal bacteria and the markers examined were found to be the following: DAPA, 0.74; D-Asp, 0.73; DGlu, 0.61. In the model experiment performed for the re-obtaining of values for protein of bacterial origin the theoretical values were determined on the basis of D-Asp and D-Glu and values approximately $10 \%$ higher than the theoretical value on the basis of DAPA. It is therefore recommended that in addition to DAPA these other two amino acids be included among the bacterial protein markers.

Keywords: D-aspartic acid, D-glutamic acid, D-amino acids, protein of bacterial origin

* To whom correspondence should be addressed.

E-mail: csapo@atk.kaposvar.pate.hu 
A common characteristic of the new protein evaluation systems introduced in cattle nutrition in a number of countries over the past decade is that the protein content of diets is judged on the basis of the quantity of amino acids absorbed from them in the small intestine of the animal. In addition to endogenous amino acids, which amount only to a small proportion, it comes, to a substantial extent, from two sources of amino acids, i.e., microbial protein synthesised in the rumen and dietary protein not broken down in the rumen (by-pass protein), which determine the quantity of amino acids absorbed. That is, on average, $70 \%$ of the protein content of the diet is broken down into amino acids in the rumen, this being utilised for the synthesis of amino acids or microbial protein or being broken down still further to provide ammonia for the construction of microbial body proteins. Ammonia not utilised for this is absorbed from the rumen and is converted into urea via the ornithine cycle in the liver. There is a further reason of importance for establishing the quantity of microbial protein produced in the rumen, since only when this quantity has been determined can the proportion of by-pass protein in the diet be established.

In order to define the quantity of microbial protein synthesised in the rumen, it is essential that microbial protein in the duodenal chyme be separable from the dietary bypass protein proportion and from the protein of endogenous origin. This is possible only if components characteristic solely of microbial protein can be identified among the total protein.

In the past years several methods have been developed for the determination of the proportion of the nitrogen-containing substances of microbial origin passed from the rumen into the abomasum or the small intestine. Attempts have been made to estimate the proportion of the content of nitrogen-containing substances of microbial origin by means of determination with nucleic acid and tracing with vitamin $\mathrm{B}_{12}$ and sulphur 35 isotope. A critical evaluation and summary of these methods was given by STERN and HOOVER (1979).

CZERKAWSKI (1974) was successful in drawing a conclusion on protozoan nitrogen by means of the measurement of 2-amino-ethylphosphonic acid and on nitrogen content of bacterial origin by measuring 2-6-diaminopimelic acid (DAPA). That is, 2amino-ethylphosphonic acid occurs to a great extent only in protozoa, while 2-6diaminopimelic acid (hereafter referred to as DAPA) occurs exclusively in peptidoglycans in the bacterial cell wall. Despite the fact that the quantity of DAPA in the cell wall is strongly dependent on the species of bacterium in question, the ratio of DAPA in relation to total bacterial protein does not vary under constant dietary conditions; therefore, in comparative experiments DAPA can be used to good effect in the estimation of the proportion of protein of bacterial origin found in the contents of the intestine. 
SCHLEIFER and KANDLER (1972) discovered that, like DAPA, D-alanine occurs also only in peptidoglycans in the bacterial cell wall and hence this compound is also suitable for use in the marking of proteins of bacterial origin and their quantitative determination. GARRETT and co-workers (1982) reported that, in the knowledge of this, they succeeded in determining nitrogen of bacterial origin by measuring the quantity of D-alanine in the ruminal fluid. GARRETT and co-workers (1987) subsequently performed comparative experiments using DAPA and D-alanine to investigate which compound enabled nitrogen of bacterial origin to be determined more precisely. They established that D-alanine proved to be a better indicator of nitrogen of bacterial origin, since the coefficient of variation resulting from the data obtained for D-alanine was substantially lower than that defined in the case of DAPA; in addition, greater accuracy was achieved in determination using D-alanine than with DAPA. In a series of experiments CSAPÓ and HENICS (1991) also established that both DAPA and D-Ala are suitable for use in the estimation of the quantity of protein of bacterial origin. No difference was observed between the two substances with respect to error either in analytical determination or in determination of protein of bacterial origin.

Several types of methods have been experimented with for the determination of DAPA in the ruminal fluid or the gut contents. HUTTON and co-workers (1971) used an automated amino acid analyser to determine DAPA, thus exploiting the characteristic of DAPA. In contrast to other amino acids but similarly to proline, it gives a yellow colour with acidic ninhydrin solution with the maximum light absorption value having been detected at a wavelength of $420 \mathrm{~nm}$. In determining DAPA CZERKAWSKI (1974) hydrolysed the protein with acid, cleaned the hydrolysate in a charcoal column, separated the DAPA from the proline in an anion exchange column and determined DAPA with acidic ninhydrin.

PONGOR and BAINTNER (1980) developed a simple and fast method using ion exchange thin layer chromatography for the determination of DAPA combined with videodensitometry; however, due to the videodensitometric evaluation element this procedure has not become widely used in practice. EDOLS (1985) determined DAPA in a hydrolysate from the ruminal fluid by the application of a two-column method using an automated amino acid analyser. By the optimisation of the composition of buffers DAPA appeared between methionine and isoleucine on the chromatogram, well separated from these two amino acids, in the form of a sharp, easily quantifiable peak. CSAPÓ and co-workers (1986b) oxidised samples with performic acid prior to protein hydrolysis, as a consequence of which - the disturbing effects of neighbouring amino acids having been eliminated - DAPA, even if present only in trace quantities, could be determined accurately. Subsequently to this, exploiting the similar representation on 
chromatograms of methionine and DAPA, the authors developed a fast method for the determination of DAPA alone by means of ion exchange column chromatography (CSAPÓ et al., 1995b).

Investigating the D-amino acid content of foodstuffs, particularly milk and milk products (CSAPÓ et al., 1995a; CSAPÓ et al., 1997a) it was observed that, in addition to D-Ala, D-glutamic acid (D-Glu) and D-aspartic acid (D-Asp) can also be detected in similar quantities, primarily in products which have links with bacterial activity. This gave rise to the idea of examining the DAPA, D-Asp and D-Glu content of bacteria extracted from the rumen of cattle and that of chyme from the same cattle, in order to determine the type of relation existing among these three components and to establish whether D-Asp and D-Glu can be used in the estimation of protein of bacterial origin.

Several methods have been developed for the separation and determination of amino acid enantiomers. Polarimetry was used for studying the racemisation of pure amino acids, and subsequently various enzyme techniques came into more general use. The flaw in such methods is that they cannot be used in the detection of trace quantities of D-amino acids, and contamination with amino acids of enzyme origin can also represent a very substantial source of error.

For the investigation of the optical purity of biologically active substances various methods using direct liquid chromatography have been developed. The essential elements of these procedures are the chiral column, consisting of chemically bound Lhydroxyproline- $\mathrm{Cu}^{2+}$ complex and the mobile phase, which is an aqueous solution containing $\mathrm{Cu}^{2+}$ ions. The application of the stationary phase creates the possibility for the investigation of the optical purity of all compounds which form chelate complexes with $\mathrm{Cu}^{2+}$ ions, for example the amino acids. The drawback of this method is that the Dand L-form of only one amino acid at a time can be determined.

WEINSTEIN and WEINER (1984) formed from amino acids the fluorescent 5dimethyl-aminonaphthalene-1-sulphonyl derivative, and by using reversed phase liquid chromatography with the application of the chiral charge of N,N'-di-n-propyl-L-alanine and copper acetate succeeded in separating - from a sample - the D- and L-enantiomers of every amino acid involved in protein formation. Using 1-fluoro-2,4-dinitrophenyl-5L-alanine amide, which contains a highly reactive fluorine atom, MARFEY (1984) created diastereoisomer derivatives, which were separable by means of liquid chromatography.

For the quantitative determination of amino acid enantiomers it is not sufficient to separate the enantiomers from each other; it must also be ensured that these enantiomers separate clearly from the other amino acids and derivatives of the latter. In addition, to achieve an appropriate degree of sensitivity amino acid derivatives detectable even in small quantities must be established. To this end there has recently been quite widespread application of pre-column derivative formation using fluorescent reagents 
and reversed phase chromatography (RPC) for derivatives. With these methods the limit of verifiability for the amino acids to be determined is very low, and the flexibility of the analytical system conceals within it exceptional benefits (EINARSSON et al., 1987). Thus, automated methods, among others, have been developed for the determination of the $\alpha$-amino acids with optically inactive o-phthalaldehyde/mercaptoethanol (OPA) (SMITH \& PANICO, 1985), and for the determination of the $\alpha$-amino acids and the imino acids together by means of 9-fluorenylmethyl chloroformate (FMOC-Cl) (CuNICO et al., 1986; BETNER \& FÖLDI, 1988).

The reaction of the optically active (chiral) amino acids with chiral reagents results in a diastereoisomer compound, which in principle cannot be separated even in a chiral column. Should the chiral reagent be another amino acid, the isolation of the diastereoisomer peptides and their determination can also be performed by means of ion exchange column chromatography (HIRSCHMANN et al., 1967; MANNING \& MOORE, 1968; IZUMIJA \& MURAOKA, 1969; CSAPÓ et al., 1989a; CSAPÓ \& CSAPÓ-KISS, 1989; CSAPÓ et al., 1989b).

Subsequent to the formation of derivatives with a chiral reagent it is possible to separate and determine the enantiomers of amino acids involved in protein formation in a single analysis by means of RPC. Since separation by chromatography may generally take 50 to $70 \mathrm{~min}$, it is very important that any analytical method developed should be completely automated. Another precondition is that such a method should centre on a simple derivative forming reaction, which should run its course within a short period at room temperature. The reaction between the optically active thiols, OPA and the amino acids to be determined has been used for the separation and determination of amino acid enantiomers (ASWAD, 1984; BUCK \& KRUMMEN, 1987; BRÜCKNER et al., 1994). The utilisation of chiral 1-(9-fluorenyl)ethyl chloroformate (FLEC) for the separation of enantiomers also entails the advantage that not only the $\alpha$-amino acids but also the imino acids form stable derivatives (EINARSSON et al., 1987).

One of the fastest methods for the separation of D- and L-amino acids is gas chromatography. The enantiomers can be separated in the form of a diastereoisomer pair created by means of an appropriate asymmetrical reagent, or alternatively the volatilised derivatives can be separated in an optically active stationary phase. Gas chromatography has been developed to such perfection that error in the determination of enantiomers is below $5 \%$, the level of repeatability being extremely high.

One of the major steps in the determination of D-amino acids is the hydrolysis of protein. It is also very important to establish whether racemisation occurs during protein hydrolysis, since, if it does, this may falsify the measurement data obtained. It has been reported in various studies that the degree of racemisation during hydrolysis is dependent upon the type of peptide or protein in question and also upon the other amino 
acids present in the environment of the amino acid to be determined; it has also been established that peptide-bonded amino acids are generally racemised more rapidly than free amino acids (LIARDON \& LEDERMAN, 1986; LIARDON \& FRIEDMAN, 1987).

Recently many researchers have experimented with the application of microwave technology in protein hydrolysis and a number of them have reported excellent results obtained with hydrolysis performed for a short period at high temperature (CHIOU \& WANG, 1988; CSAPÓ et al., 1994). If the objective is the separation and determination of amino acid enantiomers, a method of protein hydrolysis involving minimal racemisation should be selected, since should a substantial amount of racemisation occur during hydrolysis it would be impossible to establish whether a proportion of the amino acid enantiomers was originally present in the sample, or whether these enantiomers were only formed in the course of hydrolysis. Several methods have been developed for the suppression of racemisation during protein hydrolysis (SMITH et al., 1983; REDDY et al., 1989; D'ANIELLO et al., 1990), but these have proven rather lengthy and cumbersome. CSAPÓ and co-workers (1997b) have developed a protein hydrolysis procedure performed for a short period at high temperature; the authors established that any measure which accelerates protein hydrolysis reduces the degree of racemisation.

\section{Materials and methods}

\subsection{Methodology for the animal experiment}

The chyme and ruminal bacteria samples examined were taken from two experiments using five growing bulls of Hungarian Pied $\mathrm{x}$ Holstein Friesian cross origin of $480-500 \mathrm{~kg}$ body weight, each fitted with ruminal and duodenal fistulae; the objective of these experiments was to determine ruminal protein degradability for various diets, and also to establish the effect on the ruminal degradability of proteins of various types of feed additives (orthophosphoric acid, glyoxal, and a mixture of volatile oils). The diets examined included ones the protein of which is degraded in the rumen to a great extent (maize silage, extruded sunflower seed meal and molasses), to an intermediate degree (meadow hay), and only slightly (blood meal, feather meal and maize gluten).

Both experiments consisted of a ten-day adaptation period and a four-day trial period. In each trial period the degradability of the protein of a different diet and the effect exerted by a different additive was investigated. On days 1 and 4 of each experimental period samples of duodenal chyme were taken through the fistula every two hours from 6.00 to $16.00 \mathrm{~h}$, giving a total of six samples for each treatment. The chyme samples subjected to examination were formulated from these partial samples. The quantity of chyme passing through the duodenum was determined by means of $\mathrm{TiO}_{2}$ 
marker mixed into the diets. In order to establish the DAPA, D-Asp and D-Glu content of the ruminal bacteria, on day 2 of the experimental period samples of ruminal fluid were taken through the ruminal fistula three hours after morning feeding.

\subsection{Preparation of samples for chemical investigation}

In the preparation of the samples the ruminal fluid was centrifuged at 3000 rotation per minute in order to separate the feed particles from the infusorians. The bacterial mass was then separated by centrifugation of the fluid phase at 16,000 revolutions per minute; this mass was subsequently dried by means of lyophilisation. Aliquot parts of the chyme samples taken from the duodenum were also lyophilised.

\subsection{Chemical investigation of samples}

DAPA content was determined, by means of the procedure developed by CSAPÓ and co-workers (1986a) using Aminochrom-II and LKB 4101 type amino acid analysers, subsequent to protein oxidation with performic acid followed by $24-\mathrm{h}$ hydrolysis with $6 \mathrm{~mol}$ hydrochloric acid containing $0.1 \%$ phenol.

Prior to determination of D-Asp and D-Glu the protein was hydrolysed with $6 \mathrm{M}$ hydrochloric acid for $30 \mathrm{~min}$ at $170{ }^{\circ} \mathrm{C}$ in order to permit the minimum possible degree of racemisation; separation and determination of the enantiomers were performed by means of high performance liquid chromatography in accordance with the method described by EINARSSON and co-workers (1987). For derivative formation ophthalaldehyde (OPA) and 2,3,4,6-tetra-O-acetyl-1-thio- $\beta$-glucopyranoside (TATG) were purchased from Sigma (St. Louis, Mo). Enantiomer separation was performed in a reversed phase $(250 \times 4.6 \mathrm{~mm}$ internal diameter, $5 \mathrm{~mm}$ particle size, Kromasil octyl (C8) charge) analytical column. In order to lengthen the life of the column a safety column (RP8, Newguard, $25 \times 3.2 \mathrm{~mm}$ internal diameter, $7 \mathrm{~mm}$ particle size, Brownlee) was connected between the sample doser and the analytical column and a cleaning column (C18, 36 $\times 4.5 \mathrm{~mm}$ internal diameter, $20 \mathrm{~mm}$ particle size, Rsil) was fitted between the pump and the sample doser. A gradient system consisting of two components was used for enantiomer separation, the composition of this system being the following: $\mathrm{A}=$ in $40 \%$ methanol phosphate buffer $(9.5 \mathrm{mmol}, \mathrm{pH}=7.05)$; $\mathrm{B}=$ acetonitrile. The rate of flow used was $1 \mathrm{ml}$ per min.

Since in this series of experiments only the quantity of D-Asp and D-Glu was of interest to the authors, determination was confined to these two amino acids and their enantiomers. By means of this procedure D-Asp and D-Glu present even in very small quantities can be detected and determined alongside with L-amino acid present in large quantities. 


\section{Results and discussion}

The results for linear regression for the chyme and ruminal bacteria samples with respect to the relations to DAPA-D-Asp, DAPA-D-Glu and D-Asp-D-Glu are presented in Table 1. Table 2 shows the relation between crude protein content of the ruminal bacteria and chyme and D-Asp, DAPA and D-Glu for the same samples.

On analysis of the data presented in the tables it can be established that examination of both chyme and ruminal bacteria samples produced a very close correlation between DAPA and D-Asp and between DAPA and D-Glu content. The $r$ value obtained on analysis of the relation between the DAPA and D-Glu content of the chyme was the lowest, at 0.70 , and was the highest, at 0.81 , in the case of DAPA and DGlu in the ruminal bacteria. An even closer correlation was obtained on examination of the relation between D-Asp and D-Glu, both for the chyme $(r=0.95)$ and for the ruminal bacteria $(r=0.84)$.

Table 1

Linear regression parameters and statistical characteristics for chyme and ruminal bacteria with respect to DAPA-D-Asp, DAPA-D-Glu and D-Asp-D-Glu $(Y=A+B \times X)$

\begin{tabular}{|c|c|c|c|c|c|c|}
\hline \multirow{2}{*}{$\begin{array}{l}\text { Parameter, } \\
\text { statistical } \\
\text { characteristic }\end{array}$} & \multicolumn{3}{|c|}{ Chyme } & \multicolumn{3}{|c|}{ Ruminal bacteria } \\
\hline & DAPA-D-Asp & DAPA-D-Glu & D-Asp-D-Glu & DAPA-D-Asp & DAPA-D-Glu & D-Asp-D-Glu \\
\hline A & 0.31332 & 0.43877 & -0.1682 & 1.12088 & 2.68554 & 2.34587 \\
\hline $\mathrm{sd}$ & 0.08943 & 0.14195 & 0.07365 & 0.55976 & 0.43646 & 0.43684 \\
\hline B & 0.65491 & 0.82992 & 1.33064 & 0.83955 & 0.77105 & 0.72862 \\
\hline sd & 0.09351 & 0.14843 & 0.07825 & 0.18638 & 0.14533 & 0.11985 \\
\hline SD & 0.11814 & 0.18752 & 0.08323 & 0.23758 & 0.18524 & 0.16914 \\
\hline $\mathrm{N}$ & 34 & 34 & 34 & 17 & 17 & 17 \\
\hline$r$ & 0.78 & 0.70 & 0.95 & 0.76 & 0.81 & 0.84 \\
\hline $\mathrm{P}$ & $<0.0001$ & $<0.0001$ & $<0.0001$ & $<0.0001$ & $<0.0001$ & $<0.0001$ \\
\hline
\end{tabular}


Table 2

Linear regression parameters and statistical characteristics determined between crude protein and DAPA, $D$-Asp and D-Glu for ruminal bacteria and chyme $(Y=A+B \times X)$

\begin{tabular}{|c|c|c|c|c|c|c|}
\hline \multirow{2}{*}{$\begin{array}{l}\text { Parameter, } \\
\text { statistical } \\
\text { characteristic }\end{array}$} & \multicolumn{3}{|c|}{ Ruminal bacteria } & \multicolumn{3}{|c|}{ Chyme } \\
\hline & D-Asp & DAPA & D-Glu & D-Asp & DAPA & D-Glu \\
\hline A & -0.6983 & -1.7455 & 1.4848 & 1.07286 & 1.26676 & 1.30856 \\
\hline sd & 1.7043 & 1.1245 & 1.1521 & 0.3219 & 0.37937 & 0.45303 \\
\hline B & 0.08822 & 0.09608 & 0.07013 & -0.00608 & -0.01364 & -0.00394 \\
\hline sd & 0.03448 & 0.02275 & 0.0233 & 0.01305 & 0.01536 & 0.01834 \\
\hline SD & 0.32875 & 0.2169 & 0.2222 & 0.18739 & 0.22064 & 0.26348 \\
\hline $\mathrm{N}$ & 17 & 17 & 17 & 34 & 34 & 34 \\
\hline$r$ & 0.73 & 0.74 & 0.61 & -0.08 & -0.16 & -0.04 \\
\hline $\mathrm{P}$ & 0.02181 & 0.00074 & 0.00881 & 0.6442 & 0.38112 & 0.83151 \\
\hline
\end{tabular}

The very close correlations between DAPA and D-Asp, DAPA and D-Glu and the two D-amino acids (D-Asp and D-Glu) led the authors to perform further experiments in order to clarify how the two amino acids might function as markers of protein of bacterial origin, and what relation exists between bacterial markers and crude protein content. On analysis of the data presented in Table 2 it can be established that for the ruminal bacteria the closest correlation was obtained in the case of DAPA and crude protein content $(r=0.74)$; the $r$ value between D-Asp and crude protein content was only very slightly lower $(r=0.73)$, while the closeness of the relation between D-Glu and crude protein content was seen to lag somewhat behind these correlations $(r=0.61)$. However, the data obtained for the chyme samples produced no close correlation between the markers investigated and crude protein content; in fact, in the case of all three examinations linear regression analysis demonstrated a very weak negative correlation ( $r$ values varying between -0.04 and -0.16 ). This lack of correlation might be explained by the fact that only a proportion of the protein present in the chyme is derived from bacteria, the rest being comprised of dietary proteins which do not undergo bacterial degradation in the rumen, a small proportion of these being endogenous protein. Ruminal degradability of dietary proteins is on average $70 \%$. However, this average conceals a very wide distribution of values. Results from experiments performed under in vivo and in vitro conditions corroborate that there are very great differences between the individual proteins with respect to ruminal 
degradability (CHALUPA, 1976). There do exist feeds whose protein content undergoes almost total degradation in the rumen, while the ruminal degradability of other dietary proteins is only $15-20 \%$. The great deviations encountered are connected with protein structure, primarily with the number of disulphide bonds present (MANGAN, 1972). The quantity and ratio of protein fractions influence ruminal degradability (WOHLT et al., 1976), as does protein amino acid composition (TAMMINGA, 1979) and the chemical and heat treatment of protein (KAUFMANN \& LÜPPING, 1979; SCHMIDT et al., 1993). This implies that, dependent upon the proteins fed, there will always be variations in the proportions of microbial protein in the chyme and non-degradable dietary protein in the rumen.

As it was outlined in the section on methodology, in this experiment for the respective experimental periods the animals were fed diets of different ruminal degradability, which resulted in different ratios for the proportion of microbial protein and by-pass dietary protein in the chyme for the individual experimental periods. In the opinion of the authors this is the fundamental reason for the fact that in the case of chyme, in contrast to that of microbial protein, no relation was found between DAPA content and the quantity of the two D-amino acids.

By means of the linear regression parameters given in Table 2 a value of $49.05 \%$ was obtained for ruminal bacteria crude protein content on the basis of D-Asp, $49.26 \%$ on the basis of DAPA and $49.96 \%$ on the basis of D-Glu. The authors' calculations give an average value of $49.50 \%$ for ruminal crude protein content.

Subsequent to this, calculations were made with respect to the DAPA content of the ruminal bacteria obtained by means of the procedure applied, by which values of $0.606 \%$ for DAPA content, $0.740 \%$ for D-Asp content and $0.999 \%$ for D-Glu content were obtained. No possibility is available for the evaluation of the findings for D-Asp and D-Glu in the light of the relevant specialist literature, since as far as the authors are aware no other researchers have as yet carried out investigations into these components of bacterial protein. The value of $0.606 \%$ obtained for DAPA is lower than the value of $1.0 \pm 0.25 \%$ reported for bacterial protein by ORSKOV (1982) (data in the literature varying between 0.6 and $1.4 \%$ ), which may be attributable to differences in the quality of the diets fed to the experimental livestock. Since the objective of these investigations was to identify a new marker for bacteria, it can be affirmed that the relative deviation in DAPA content observed, on comparison with data in the literature, does not influence the results obtained for D-Asp and D-Glu in this study.

After analysis of ruminal bacteria, and in the possession of data on crude protein content, multiplying factors were calculated to enable the proportion of protein of bacterial origin in an unknown sample to be estimated on the basis of DAPA, D-Asp and D-Glu content. The multiplying factor used for DAPA was $100 / 0.606=165$; for DAsp, 100/0.740 = 135; and for D-Glu, 100/0.999 $=100$. 
In order to establish the applicability in practice of the multiplying factors calculated in this study, two experiments were performed. In the first these multiplying factors were applied to analysis data obtained for various chyme samples. The results obtained are presented in Table 3. From these data it can be seen that, with two exceptions, values estimated on the basis of DAPA content are on average $10 \%$ higher than the microbial protein quantities determined on the basis of D-Glu or D-Asp content. The explanation for this may be that the DAPA content of ruminal bacteria calculated by the authors was somewhat lower than data reported in the literature. When protein content determined on the basis of D-Glu is compared with that for which D-Asp was the starting point, the level of concordance is immediately visible; in the majority of cases the respective values obtained concur almost entirely.

In the second part of the investigation performed to test the multiplying factors calculated a mean sample was produced from the 17 lyophilised ruminal bacteria samples available. The crude protein content of this mean sample was calculated at $49.5 \%$, its DAPA content at $0.325 \%$, its D-Asp content at $0.364 \%$ and its D-Glu content at $0.492 \%$. By application of the multiplying factors obtained from the study crude protein content values of $53.63 \%, 49.14 \%$ and $49.20 \%$, respectively, were estimated.

Table 3

Examples of the application of multiplying factors in the determination of protein of bacterial origin content of chyme samples

\begin{tabular}{|c|c|c|c|c|c|c|}
\hline \multirow{2}{*}{$\begin{array}{l}\text { Chyme } \\
\text { sample }\end{array}$} & \multicolumn{3}{|c|}{ Analysis results } & \multicolumn{3}{|c|}{$\begin{array}{l}\text { Protein of bacterial origin }(\%) \\
\text { calculated on the basis of }\end{array}$} \\
\hline & $\begin{array}{l}\text { D-Asp } \\
(\%)\end{array}$ & $\begin{array}{l}\text { DAPA } \\
(\%)\end{array}$ & $\begin{array}{l}\text { D-Glu } \\
(\%)\end{array}$ & D-Asp & DAPA & D-Glu \\
\hline 1 & 0.08546 & 0.07630 & 0.11513 & 11.54 & 12.59 & 11.67 \\
\hline 2 & 0.06681 & 0.05814 & 0.08935 & 9.03 & 9.59 & 9.06 \\
\hline 3 & 0.12546 & 0.11276 & 0.16415 & 16.96 & 18.61 & 16.64 \\
\hline 4 & 0.07402 & 0.06560 & 0.10342 & 10.01 & 10.82 & 10.49 \\
\hline 5 & 0.06519 & 0.05249 & 0.08644 & 8.81 & 8.66 & 8.77 \\
\hline 6 & 0.10546 & 0.09933 & 0.13637 & 14.26 & 16.38 & 13.83 \\
\hline 7 & 0.08564 & 0.07666 & 0.09952 & 11.58 & 12.64 & 10.09 \\
\hline 8 & 0.08671 & 0.07041 & 0.11865 & 11.72 & 11.61 & 12.03 \\
\hline 9 & 0.08591 & 0.08090 & 0.11730 & 11.61 & 13.34 & 11.89 \\
\hline 10 & 0.09230 & 0.08189 & 0.12402 & 12.48 & 13.50 & 12.58 \\
\hline
\end{tabular}


Table 4

Model experiment to investigate the accuracy of determination of protein of bacterial origin

1st sample (with $24.76 \%$ (calculated) protein of bacterial origin)

\begin{tabular}{|c|c|c|c|c|c|c|}
\hline \multirow{2}{*}{$\begin{array}{l}\text { Parallel } \\
\text { analyses }\end{array}$} & \multicolumn{3}{|c|}{ Analysis results } & \multicolumn{3}{|c|}{$\begin{array}{l}\text { Protein of bacterial origin }(\%) \\
\text { calculated on the basis of }\end{array}$} \\
\hline & $\begin{array}{l}\text { D-Asp } \\
(\%)\end{array}$ & $\begin{array}{l}\text { DAPA } \\
(\%)\end{array}$ & $\begin{array}{l}\text { D-Glu } \\
(\%)\end{array}$ & D-Asp & DAPA & D-Glu \\
\hline 1 & 0.182 & 0.162 & 0.247 & 24.60 & 26.71 & 25.05 \\
\hline 2 & 0.181 & 0.159 & 0.239 & 24.47 & 26.22 & 24.24 \\
\hline 3 & 0.179 & 0.155 & 0.251 & 24.20 & 25.56 & 25.45 \\
\hline 4 & 0.184 & 0.164 & 0.241 & 24.87 & 27.04 & 24.44 \\
\hline 5 & 0.185 & 0.166 & 0.246 & 25.01 & 27.37 & 24.94 \\
\hline Mean & 0.1822 & 0.1612 & 0.2448 & 24.63 & 26.58 & 24.82 \\
\hline SD & 0.0021 & 0.0038 & 0.0043 & 0.287 & 0.636 & 0.430 \\
\hline
\end{tabular}

2nd sample (with $4.952 \%$ (calculated) protein of bacterial origin)

\begin{tabular}{llcccccc}
\hline & \multicolumn{3}{c}{ Analysis results } & & \multicolumn{2}{c}{$\begin{array}{c}\text { Protein of bacterial origin }(\%) \\
\text { calculated on the basis of }\end{array}$} \\
\cline { 2 - 3 } $\begin{array}{l}\text { Parallel } \\
\text { analyses }\end{array}$ & $\begin{array}{c}\text { D-Asp } \\
(\%)\end{array}$ & $\begin{array}{c}\text { DAPA } \\
(\%)\end{array}$ & $\begin{array}{c}\text { D-Glu } \\
(\%)\end{array}$ & & D-Asp & DAPA & D-Glu \\
1 & 0.037 & 0.037 & 0.047 & & 5.001 & 6.101 & 4.766 \\
2 & 0.035 & 0.035 & 0.049 & & 4.731 & 5.772 & 4.969 \\
3 & 0.038 & 0.032 & 0.051 & & 5.136 & 5.277 & 5.171 \\
4 & 0.034 & 0.031 & 0.046 & & 4.596 & 5.112 & 4.664 \\
5 & 0.037 & 0.033 & 0.047 & & 5.001 & 5.442 & 4.766 \\
Mean & 0.362 & 0.0336 & 0.0480 & & 4.893 & 5.541 & 4.867 \\
SD & 0.0015 & 0.0022 & 0.0018 & & 0.198 & 0.355 & 0.181 \\
\hline
\end{tabular}

Subsequently, the authors produced from beef by means of lyophilisation a meat meal of zero DAPA content and whose D-Asp and D-Glu content (racemisation testing being performed during protein hydrolysis) was, after hydrolysis of its protein using the method applied by the authors, found to be below $0.01 \%$ with respect to both glutamic acid and aspartic acid. For the first batch $1 \mathrm{~g}$ meat meal was mixed into $1 \mathrm{~g}$ bacterium sample and DAPA, D-Asp and D-Glu content were determined using 5 replicate analyses. This was then repeated using $9 \mathrm{~g}$ meat meal mixed with $1 \mathrm{~g}$ bacterium sample. The results obtained are presented in Table 4 . 
From the data given in the table it can be established that the dispersion percentages for the first sample, containing a higher quantity of bacterial protein, are in each case below $5 \%$; thus the dispersion of the results meets the requirements for a reliable analytical method. For the second sample, in which the proportion of bacterial protein was only $20 \%$ of that in the first sample, with the exception of DAPA the dispersion percentage in each case remained below $5 \%$, while that calculated for DAPA exceeded that value slightly. On comparison with the calculated values of the crude protein content obtained from the analysis data it can be ascertained that the results obtained for DAPA were, in the case of samples 1 and 2, approximately $10-15 \%$ higher than the anticipated values, while the values calculated on the basis of D-Asp and D-Glu practically concurred entirely with the expected values.

\section{Conclusions}

The investigations performed have provided evidence that both D-Asp and D-Glu may be appropriate for the determination of protein of bacterial origin. The results obtained using the two new bacteria markers proved to be approximately $10 \%$ lower than those obtained using DAPA, this being due not to error attributable to the new markers but rather to the unreliability of determination using DAPA. The analyses performed on samples of known bacterial protein content indicate that D-Asp and D-Glu on the one hand gave practically identical values for bacterial protein content, and on the other hand both provided results were very close to the theoretical (calculated) values.

The preparation process in the case of DAPA is lengthy due to the treatment with performic acid required. However, without performic acid treatment the determination of DAPA present in small quantities is unreliable, due to other amino acids in concentrations which may in some cases be higher by several orders of magnitude. In addition to the large amount of work required for the process, determination using DAPA also requires more time and more chemical agents, and is therefore fairly expensive. At the same time, an amino acid analyser operating on the principle of ion exchange column chromatography is suitable for analysis with DAPA, while separation of the D-amino acids cannot be performed with an amino acid analyser operating on the traditional principle.

Determination using D-Asp and D-Glu can be carried out with precision by means of high performance liquid chromatography. By the application of the fast procedure developed by the authors the determination of the quantity of D-Asp and D-Glu can be performed in a quarter of the amount of time required for ion exchange column chromatography analysis using DAPA. A different problem emerges in the determination of D-amino acids: that is, racemisation occurring during protein hydrolysis, which can falsify the experimental results obtained. Therefore, due to 
racemisation greater quantities of D-Asp and D-Glu can be measured, leading to overestimation of the amount of protein of bacterial origin present. Two methods are recommended for the elimination of this source of error. One is the application of a hydrolysis procedure which allows only a very low degree of racemisation to take place (for example, the protein hydrolysis method developed by the authors, performed at high temperature and for a short period, i.e., $160-170{ }^{\circ} \mathrm{C}$ for $30-45 \mathrm{~min}$ ). The other method is to determine by means of the method to be applied the D-Asp and D-Glu content of bacteria obtained from the rumen, following which, in a procedure similar to that used by the authors, multiplying factors should be calculated for the estimation of the quantity of protein of bacterial origin. In the case of the latter racemisation occurring during protein hydrolysis is to be regarded as a constant error, both in the calculation of multiplying factors and in the analysis of real samples, and therefore it exerts no substantial influence upon the accuracy of the determination procedure. Thus, method application is affected by the minimum of error if a protein hydrolysis procedure involving a low degree of racemisation is used, and if multiplying factors are determined by means of the method applied.

The financial support of National Fund for Scientific Research (OTKA T 14916, OTKA 032411) and Ministry of Education (MKM-15) is gratefully acknowledged.

\section{References}

ASWAD, D. W. (1984): Determination of D- and L-aspartate in amino acid mixtures by high performance liquid chromatography after derivatisation with chiral adduct of o-phthalaldehyde. Anal. Biochem., 137,405 .

BETNER, I. \& FÖLDI, P. (1988): The FMOC-ADAM approach to amino acid analysis. LC. GC., 832.

BRÜCKNER, H., HAASMANN, S., LANGER, M., WESTHAUSER, T., WITTNER, R. \& GODEL, H. (1994): Liquid chromatographic determination of D- and L-amino acids by derivatization with o-phthaldialdehyde and chiral tiols. J. Chromat. A., 666, 259-273.

BUCK, R. H. \& KRUMMEN, K. (1987): High performance liquid chromatography determination of enantiomeric amino acids and amino alcohols after derivatisation with o-phthalaldehyde and various chiral mercaptans. J. Chromat., 387, 255.

CHALuPA, W. (1976): Degradation of amino acids by the mixed rumen microbial population. J. Anim. Sci., $43,828-834$.

CHIOU, S. H. \& WANG, K. T. (1988): Simplified protein hydrolysis with methanesulphonic acid at elevated temperature for the complete amino acid analysis of proteins. Chromatography, 448, 404-410.

CSAPÓ. J. \& CSAPÓ-KISS, ZS. (1989): D- és L-aminosavak elválasztása és meghatározása ioncserés oszlopkromatográfiával diasztereoizomer dipeptid formában. I. Az alanil dipeptidek szétválasztása és meghatározása. (Separation and determination of D- and L-amino acids in diastereoisomer dipeptide form by means of ion exchange column chromatography. I. Separation and determination of alanyl dipeptides.) Élelmiszervizsgálati Közlemények, 35, 140-152. 
CSAPÓ, J. \& HENICS, Z. (1991): Quantitative determination of bacterial protein from the diaminopimelic acid and D-alanine content of rumen liquor and intestines. Acta agron. Hung., 20, 159-173.

CSAPÓ, J., TÓTH-PÓSFAI, I. \& CSAPÓ-KISS, ZS. (1986): Optimisation of hydrolysis at determination of amino acid content in food and feed products. Acta Alimentaria, 15, 3-21.

CSAPÓ, J., GOMBOS, S., HENICS, Z. \& TÓTH, L. (1986): Modified method of diaminopimelic acid determination in samples of biological origin. Acta Alimentaria, 15, 159-167.

CSAPÓ, J., CSAPÓ-KISS, ZS., PENKE, B. \& TÓTH-PÓSFAI, I. (1989a): Separation and determination of D- and L-amino acids by ion exchange column chromatography in the form of diastereoisomer dipeptides. Acta Alimentaria, 18, 399-417.

CSAPÓ, J., CSAPÓ-KISS, ZS. \& PENKE, B. (1989b): D- és L-aminosavak elválasztása és meghatározása ioncserés oszlopkromatográfiával diasztereomer dipeptid formában. II. A 2-szulfonsav-alanil dipeptidek szétválasztása és meghatározása. (Separation and determination of D- and L-amino acids in diastereoisomer dipeptide form by means of ion exchange column chromatography. II. Separation and determination of 2-sulphonic acid-alanyl dipeptides.) Élelmiszervizsgálati Közlemények, 35, 201-208.

CSAPÓ, J., CSAPÓ-KISS, ZS., FOLESTAD, S. \& TIVESTEN, A. (1994): Mercaptoethanesulphonic acid as a protecting and hydrolysing agent for the determination of the amino acid composition of proteins using an elevated temperature for protein hydrolysis. Anal. Chim. Acta, 289, 105-111.

CSAPÓ, J., MARTIN, T. G., CSAPÓ-KISS, ZS., STEFLER, J. \& NÉMETHY, S. (1995a): Influence of udder inflammation on the D-amino acid content of milk. J. Dairy Sci., 78, 2375-2381.

CSAPÓ, J., CSAPÓ-KISS, ZS., CSORDÁS, E., MARTIN, T. G., FOlESTAD, S., TIVESTEN, A. \& NÉMETHY, S. (1995b): Rapid method for the determination of diaminopimelic acid using ion exchange column chromatography. Analyt. Letters, 28, 2049-2061.

CSAPÓ, J., CSAPÓ-KISS, ZS., CSORDÁS, E., FOX, P. F., WÁGNER, L. \& TÁLOS, T. (1997a): Különbözõ technológiával készült sajtok összes szabad- és szabad D-aminosav tartalma. (Total free and free amino acid content of cheeses produced using various technological methods.) Tejipar, 57, 25-30.

CSAPÓ, J., CSAPÓ-KisS, ZS., FOLESTAD, S., TIVESTEN, A., NÉMETHY, S., WÁGNER, L., TÁlOS, T. \& MARTIN, T.G. (1997b): Hydrolysis of proteins performed at high temperatures and for short times with reduced racemisation, in order to determine the enantiomers of D- and L-amino acids. Analyt. Chim. Acta, $339,99-107$.

Cunico, R., MAJER, A. G., WeHR, C. T. \& SHEEHAN, T. L. (1986): High sensitivity amino acid analysis using a novel automated precolumn derivatisation system. BioChromatography, 1, 1-14.

CZERKAWSKI, W. J. (1974): Methods for determining 2-6-diaminopimelic acid and 2-amino-ethylphosphonic acid in gut contents. J. Sci. Fd. Agric., 25, 45-55.

D’AnIEllo, A., D'ONOFRIO, G. \& PICHETOLA, M. (1990): Total hydrolysis with strongly reduced racemisation of amino acids. Biochim. Biophys. Acta, 1037, 200-208.

EDOLS, R. W. (1985): Simple method for the determination of diaminopimelic acid in rumen liquor hydrolysates. J. Chromat., 329, 199-201.

EINARSSON, S., FOlESTAD, S. \& JOSEFSSON, B. (1987): Separation of amino acid enantiomers using precolumn derivatisation with o-phthalaldehyde and 2,3,4,6,-tetra-O-acetyl-1-thio-b-glucopyranoside. J. Liquid Chromat., 10, 1589-1598.

GARRETT, J. E., GOODRICH, R. D. \& MEISKE, J. C. (1982): Measurement of bacterial nitrogen using Dalanine. Protein requirements for cattle. Symposium. Oklahoma State University, MP-109.

GARRETT, J. E., GOODRICH, R. D. \& MEISKE, J. C. (1987): Measurement and use of D-alanine as a bacterial marker. Can. J. Anim. Sci., 67, 735-743.

HiRSCHMANN, R., STRACHAN, R. G., SCHWANN, H., SCHOENEWALDT, E. F., JOSHUA, H., BARKENMEYER, B., WeBER, D. F., PALEVADA, W. J., JACOB, T. A., BEESLEy, T. E. \& DENKEWALTER, R. G. (1967): The controlled synthesis of peptides in aqueous medium. III. Use of Leuchs' anhidrides in the synthesis of dipeptides. Mechanism and control of side reactions. J. org. Chem., 32, 3415.

HUTTON, K., BAILEY, F. J. \& ANNISON, E. E. (1971): Measurement of the bacterial nitrogen entering the duodenum of the ruminant using diaminopimelic acid as a marker. Br. J. Nutr., 15, 165-173. 
IZUMiJA, N. \& MuraOKA, M. (1969): A racemisation test in peptide synthesis. J. Am. Chem. Soc., 91, 2391-2392.

KAUFMANN, W. \& LÜPPING, W., (1979): Zum Einfluss von protected Protein und HMM-Ca auf die Leistung von Milchküchen. Tierphisiol., Tierernähr. Futtelmittelk., 41, 202-217.

LIARDON, R. \& LEDERMAN, S. (1986): Racemisation kinetics of free and protein-bound amino acids under moderate alkaline treatment. J. agric. Fd Chem., 34, 557.

LIARDON, R. \& FRIEDMAN, M. (1987): Effect of peptide bond cleavage on the racemisation of amino acid residues in proteins. J. agric. Fd Chem., 35, 661-667.

MANGAN, J. L. (1972): Quantitative studies on nitrogen metabolism in the bovine rumen. 1. The rate of proteolysis of casein and ovalbumine and the release and metabolism of free amino acids. Brit. J. Nutr., 27, 261-283.

MANNING, J. M. \& MOORE, S. (1968): Determination of D- and L-amino acids by ion exchange chromatography as L-D and L-L dipeptides. J. biol. Chem., 243, 5591-5597.

MARFEY, P. (1984): Determination of D-amino acids. II. Use of a bifunctional reagent, 1,5-difluoro-2,4dinitrobenzene. Carlberg. Res. Commun., 49, 591-596.

ORSKOV, O. R. (1982): Protein nutrition in ruminants. Rumen microorganisms and their nutrion. Academic Press, London, pp. 19-41.

PONGOR, S. \& BAINTNER, K. (1980): Quantitative evaluation of ion exchange thin-layer chromatograms by videodensitometry (IV.) Determination of diaminopimelic acid. Acta Biochem. Biophys. Acad. Sci. Hung., 15, 1-4.

REDDY, G. S., REDDY, S. V. \& SMTTH, G. G. (1989): The effect of Ni(II), Cu(II), Co(II) and Pd(II) ions on racemisation of hydroxy $\alpha$-amino acids. Inorg. Chim. Acta, 166, 55-58.

SCHLEIFER, K. H. \& KANDLER, O. (1972): Peptidoglycan type of bacterial cell walls and their taxonomic implications. Bacteriol. Rev., 36, 407-477.

SCHMIDT, J., CENKVÁRI É., SiPÖCZ, J. \& GERGÁCZ, Z. (1993): Wirkung der Extrudierung auf den Abbau des Eiweisses im Pansen. Acta agron. Óvariensis, 35, 147-154.

SMTTH, R. J. \& PANICO, K. A. (1985): Automated analysis of o-phthalaldehyde derivatives of amino acids in physiological fluids by reversed phase high performance liquid chromatography. J. Liquid Chromatogr., 8, 1873.

SMTTH, G. G., KHATIB, A. \& REDDY, G. S. (1983): Effect of nickel (II) and other metal ions on the racemisation of free and bound L-alanine. J. Am. Chem. Soc., 105, 293-295.

STERN, M. D. \& HOOVER, W. H. (1979): Methods for determining and factors affecting rumen microbial synthesis: A review. J. Anim. Sci., 49, 1590-1603.

TAMMINGA, S. (1979): Relation between different carbohydrates and microbial synthesis of protein. Kiel Goup Seminar. Uppsala. Report No. 130.

WOHLT, J. E., SNIFFEN, C. J., HOOVER, W. H., JOHNSON, L. L. \& WALKER, C. K. (1976): Nitrogen metabolism in weeters as affected by dietary protein solubility and amino acid profile. J. Anim. Sci., $42,1280-1289$.

WEINSTEIN, S. \& WEINER, S. (1984): Enantiomeric analysis of a mixture of the common protein amino acids and their DNS derivatives. Chromatography., 303, 244-250. 